Arq. Bras. Med. Vet. Zootec., v.71, n.3, p.828-832, 2019

\title{
Type II retrocaval ureter causing hydronephrosis in a cat: case report
}

[Ureter retrocava tipo II causando hidronefrose em um gato: relato de caso]

\author{
V.G.P. Albernaz ${ }^{1}$, U.I. Tasqueti ${ }^{2}$, F. Meyer ${ }^{2}$, L.C. Miara $^{2}$, \\ I.A. Fabris ${ }^{1}$, J.G. Quitzan ${ }^{1}$ * \\ ${ }^{1}$ Universidade Estadual Paulista - Botucatu, SP \\ ${ }^{2}$ Pontifícia Universidade Católica do Paraná - Curitiba, PR
}

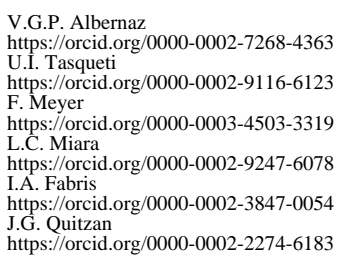

V.G.P. Alberna $2-7268-4363$ https://orcid.org/0000-0002-9116-6123 F. Meyer https://orci I.A. Fabris https://orcid.org/0000-0002-3847-0054 https://orcid.org/0000-0002-2274-6183

\begin{abstract}
Retrocaval ureter (RU) is an abnormal embryonic development of the caudal vena cava (CVC) that leads the ureter to be entrapped dorsal to the CVC. In most cases there is no clinical impact; however, it can cause hydronephrosis. We report a rare case of type II symptomatic retrocaval ureter in a feline treated with nephroureterectomy. A 4-year-old, intact male, mixed breed cat was submitted to abdominal ultrasound and severe right hydronephrosis was diagnosed, with no signs of obstruction. We performed an exploratory celiotomy, in which a displacement of the right ureter dorsal to the CVC was observed. The animal was treated with ureteronephrectomy and recovered well. No intraluminal cause was found, and a urethral catheter could be easily inserted across the ureter length. The real clinical relevance of the RU is unknown, since it is a common find in post-mortem examination without kidney impact and, when significant, is often associated to other causes of ureteral obstructions, such as calculi and strictures. Additionally, in humans, type II RU seldom develops obstruction and hydronephrosis. In our case, due to absence of other causes of obstruction, probably mechanical compression of the CVC against the psoas muscle caused the hydronephrosis.
\end{abstract}

Keywords: circumcaval, megaureter, nephrectomy, vena cava, feline

\section{RESUMO}

O ureter retrocava (UR) é originado por uma falha na formação embriológica da veia cava caudal (VCC), que leva ao aprisionamento do ureter dorsal à VCC. Na maioria dos casos, não há impacto clínico; entretanto, essa anomalia pode causar hidronefrose. Relata-se um raro caso de UR tipo II sintomático em um felino, tratado com nefroureterectomia. O referido animal, sem raça definida, macho intacto de quatro anos de idade, foi submetido à ultrassonografia abdominal, que revelou acentuada hidronefrose direita, sem sinais de obstrução. Realizou-se celiotomia exploratória, na qual foi possível observar o ureter direito dorsal à VCC. O animal foi tratado com nefroureterectomia e se recuperou satisfatoriamente. Nenhuma causa intraluminal foi encontrada e um cateter uretral pôde ser facilmente inserido por todo o comprimento do ureter. A real relevância clínica do UR é desconhecida, visto que é um achado comum em exames post mortem, sem impacto aos rins e, quando significante, frequentemente está associado a outras causas de obstrução ureteral, como cálculos e estenoses. Adicionalmente, em humanos, o UR tipo II raramente desenvolve obstrução e hidronefrose. Neste caso, devido à ausência de outros motivos de obstrução, acredita-se que a compressão mecânica da VCC contra o músculo psoas foi a causa da hidronefrose.

Palavras-chave: circumcaval, megaureter, nefrectomia, veia cava, felino

\section{INTRODUCTION}

Retrocaval ureter (RU), also known as circumcaval ureter, is a rare congenital anomaly of the caudal vena cava (CVC), in which the ureter is abnormally displaced dorsal to the CVC and between the aorta and dorsal muscles (Salonia et al., 2006; Basok et al., 2008; Bélanger et al., 2014). The normal ureter leaves the renal pelvis dorsolateral to the renal

Recebido em 20 de agosto de 2017

Aceito em 2 de julho de 2018

*Autor para correspondência (corresponding author)

E-mail: j.quitzan@unesp.br 
vessels, courses ventral to the psoas major and minor in the retroperitoneal space and goes just lateral to the CVC, ventral to the external iliac vessels toward the trigone of the urinary bladder (Evans and De LaHunta, 2013). The CVC originates from the embryogenic venous system consisted of the posterior cardinal, the subcardinal and the supracardinal veins (Bass et al., 2000). The posterior cardinal veins are located ventral to the developing ureter, and persist after birth, instead of receding, pushing the ureter toward midline to become entrapped dorsal to the CVC, leading to a RU (Bass et al., 2000; Bélanger et al., 2014). It almost always occurs on the right ureter (Bass et al., 2000).

In human patients, it occurs more frequently in male and usually remains asymptomatic until the $3^{\text {rd }}$ or $4^{\text {th }}$ decades of life (Salonia et al., 2006). In most feline patients, RU is an incidental finding with no clinical relevance (Bélanger et al., 2014), but can be associated with obstructive ureteral strictures. In these animals, the clinical signs are associated with a stricture and obstructions, rather than a RU (Steinhaus et al., 2015). Clinical signs of ureteral obstruction can be nonspecific, such as vomiting, lethargy, reduced appetite, and weight loss (Horowitz et al., 2013; Steinhaus et al., 2015).

Diagnosis is achieved with imaging exams, such as excretory urography, retrograde pyelography, venocavography, contrast-enhanced computed tomography, and MRI urography (Duconseille et al., 2010). It is most commonly diagnosed during surgical exploration or necropsy (Bélanger et al., 2014; Steinhaus et al., 2015).

Two types of RU are described in humans - type I and II. The most common is type I, where an acute medial deviation of the ureter causes a "Fish-hook" deformity leading often to symptomatic patients; and the rare, generally asymptomatic type II, when the ureter passes around the CVC at the ureteropelvic junction (Basok et al. 2008; Salonia et al., 2006). This case report aims to describe a rare case of feline type II RU causing severe hydronephrosis, without any other obstructive cause and successfully treated with nephroureterectomy.

\section{CASE}

A 4-years-old, intact male, mixed breed cat was admitted for treatment of presumptive feline lower urinary tract disease. The cat had a three days history of strangury and dysuria. A physical examination revealed the presence of hypogastric pain and full urinary bladder. Complete blood count was within normal ranges and serum biochemical analysis showed severely increased blood urea nitrogen and creatinine. During urinary bladder massage, the animal voided and excreted mucous plugs from the distal urethra. Survey ultrasonography examination revealed right hydronephrosis with proximal ureteral enlargement by anechoic content.

The animal received a post obstruction treatment based on intravenous fluid therapy with ringer lactate' solution. The treatment reestablished normal renal function and general medical condition to allow an excretory urethrography to be performed. The contrast radiography showed right hydronephrosis, proximal right megaureter, and decreased kidney filtration. The exact obstruction location could not be accessed, and no signs of extra-luminal compression or urinary calculi were found.

Due to suspected right ureteral obstruction, we performed an exploratory celiotomy. During the procedure, the right ureter was proximally enlarged, abnormally displaced medially, underneath the $\mathrm{CVC}$, and after that, running laterally over the vein to the bladder (Figure 1A and 1B). Careful dissection of the right retroperitoneal fat and the right ureter path was performed, followed by right nephrouretecrectomy with double ligation of the renal artery and vein using 2-0 polyglactin 910 (Figure 1C). The distal ureter was also double ligated near the urinary bladder with the same technique. After longitudinal section of the kidney, severe renal pelvis dilation was also seen (Figure 1D). A 4 Fr urinary catheter was passed through the renal pelvis caudally until the urinary bladder and no intraluminal obstruction was detected. No macroscopic abnormality could be found in the left kidney and ureter. 


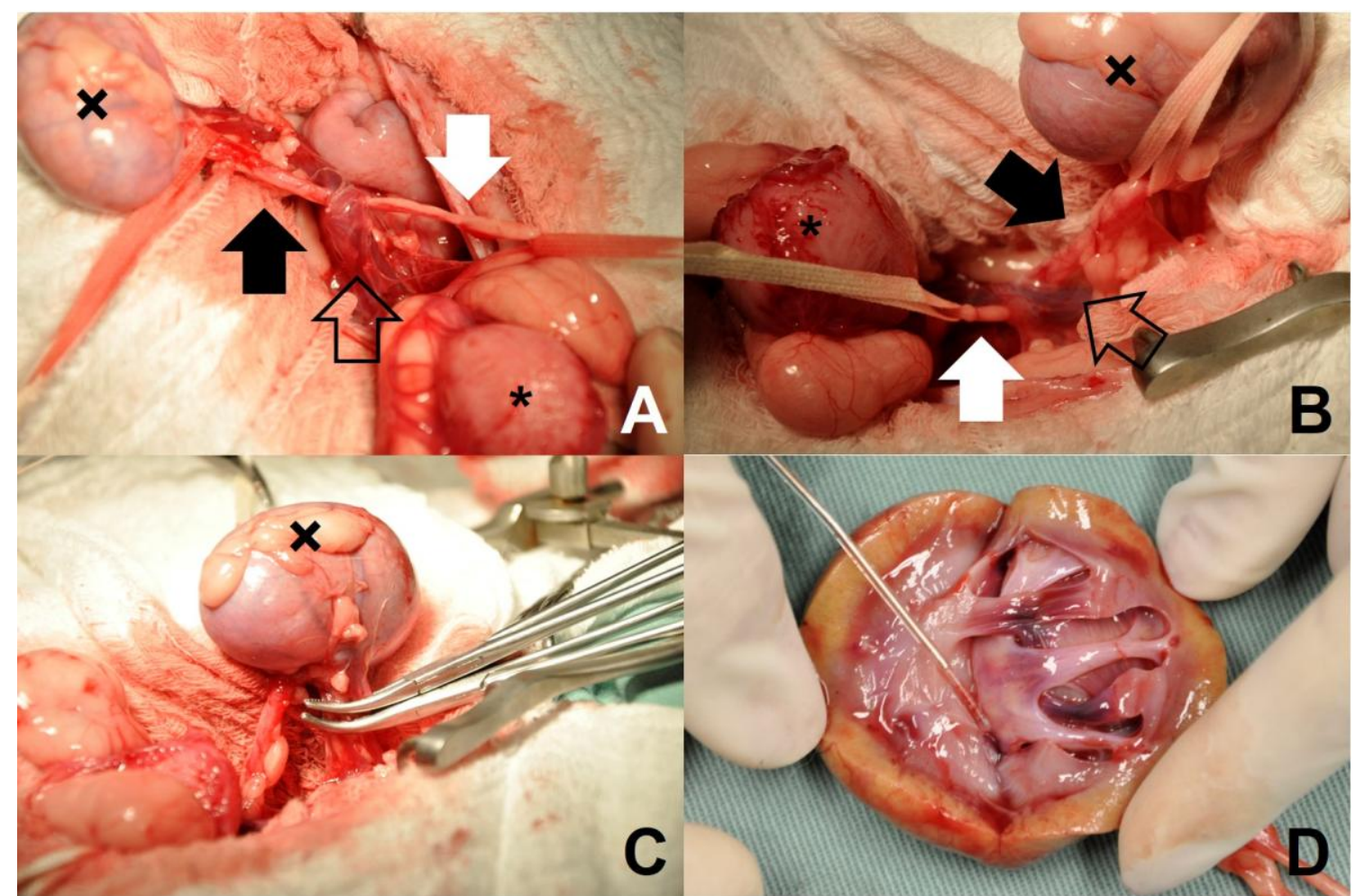

Figure 1. Intraoperative view of a RU in a cat after complete removal of all retroperitoneal attachment to right kidney and peri-ureteral fat. (A) The proximal distended RU can be seen (black arrow) leaving the right kidney $(\mathrm{x})$, crossing dorsal to the vena cava (open arrow), and running (white arrow) to the dorsalcranial aspect of the urinary bladder (*). (B) A left view of the same picture as A. (C) Nephrectomy of the right kidney $(\mathrm{x})$ with ligation of the renal artery and vein. (D) Longitudinal section of the right kidney and pelvis with dilatation. The tip of the catheter is inside the pelvis and ureter.

After surgical intervention, the patient recovered well, and was discharged from hospital on the third-day post-surgery. The patient remained stable, without any signs compatible with the disease.

\section{DISCUSSION}

In feline patients, the real clinical relevance of RU is unknown, since most studies are postmortem and there is a possibility of the animal to die before developing clinical signs (Bélanger et al., 2014). However, RU is often associated with other causes of ureteral obstruction, such as calculi $(60 \%)$, strictures $(24 \%)$ or both $(16 \%)$ (Steinhaus et al., 2015). In this case report, all image exams, surgical exploration, and ureteral patency test with a urinary catheter did not found any calculi or stricture, suggesting that the mechanical compression of the CVC and the psoas muscle could be the cause of the megaureter and hydronephrosis, as occurs in human urology (Salonia et al., 2006).

Similarly, people with RU remain asymptomatic, and the clinical signs are usually due to hydronephrosis (Basok et al., 2008), caused by the compression of the ureter, against the anomalous vessels (Bhattacharjee et al., 2016) along with the compression caused by the psoas muscle, and spinal column (Salonia et al., 2006; Basok et al., 2008; Casteleyn et al., 2015). Human patients present unspecific symptomatology, such as abdominal and flank pain, urinary tract infection, fever, and hematuria, usually associated with ureteric obstruction (Salonia et al., 2006). The clinical signs the cat showed could not differentiate the RU of other causes of urinary tract obstruction, even considering the patient was previously diagnosed with obstructive feline lower urinary tract disease. Other reports of RU cases could not distinguish between the diseases from other 
causes of obstructed ureters (Steinhaus et al., 2015). Despite impairment of the right ureter only, azotemia was present in serum biochemistry, although the previous urethral obstruction was assumed as an aggravating factor. After surgical removal of the right kidney, the azotemia was not present. Nonetheless, concurrent chronic kidney disease can be present in unilaterally affected patients, enhancing the importance of staging and monitoring of these animals (Horowitz et al., 2013; Steinhaus et al., 2015).

Imaging exams, as excretory urography and retrograde pyelography can provide the diagnosis of RU (Duconseille et al., 2010). If the diagnosis is not established with these methods, retrograde pyelography in combination with cavography has been used (Duconseille et al., 2010). Even though intravenous urography can show renal pelvis dilatation, calyces and upper ureter above the obstruction, the position of the CVC may cover the affected portion of the ureter resulting in false negative (Salonia et al., 2006). Nevertheless, these are invasive procedures (Duconseille et al., 2010). Computed tomography and MRI (Duconseille et al., 2010) are the tools of choice to prove the diagnose of RU, as they are not invasive methods and demonstrate accurately the anatomic relationship of the ureter and the CVC. However, unlike what occurs in medicine (i.e. minimal invasive procedures and endosurgery), most causes of ureter diseases in cats require surgical intervention, turning pre-operative image exams, such as CT scans and venography unnecessary (Steinhaus et al., 2015).

In our patient, we performed contrasted radiography that revealed right hydronephrosis and right proximal megaureter but did not show any sign of extraluminal obstruction or calculi. Because of the absence of a "Fish-hook" shape typical of type I RU, it was not possible to diagnose the disease before surgical exploration (Steinhaus et al., 2015). In a retrospective postmortem evaluation of cats, $35.2 \%$ had ureteral anomaly compatible with the type I RU (Bélanger et al., 2014). Therefore, we performed an exploratory celiotomy to search for the cause of the suspected obstruction and confirmed to be a type II RU. Even though there are image exams to confirm the RU, this condition is usually an accidental finding during surgical exploration or post-mortem examination in cats, as it has no specific clinical signs (Bélanger et al., 2014; Steinhaus et al., 2015).

The treatment of human patients with clinical repercussion is based on surgical repair, while patients with no symptoms should be observed, and those with no obstruction or hydronephrosis should be treated conservatively (Salonia et al., 2006). The choice of surgical technique and approach lies in the severity of hydronephrosis, the impairment of kidney function, and the type of anomaly found (Salonia et al., 2006). The surgical management can be either open or laparoscopic (Bhattacharjee et al., 2016). Some surgical techniques suggest the transection of the ureter with ureteroureteral anastomosis, reallocating the ureter in its right anatomic location (Salonia et al., 2006). Division of the dilated renal pelvis with transposition and anastomosis, ureterotomy or resection of the stenotic segment of ureter compressed by the anomalous vessel with anastomosis of a double-J stent, and ligation or transection of the CVC with or without anastomosis are also procedures indicated in case of RU (Salonia et al., 2006; Bhattacharjee et al., 2016). In symptomatic type II, the ureteropelvic junction can be excised and anastomosed to the renal pelvis after been spatulated (Basok et al., 2008).

In animals, these criteria can be used to evaluate the surgical options as well. Pigtail ureteral stents and SUB devices were used to treat obstructions, with similar outcomes than non-RU patients (Zaid et al. 2011; Horowitz et al., 2013; Steinhaus et al., 2015). If hydronephrosis is too severe or if infection is present, nephrectomy is indicated (Salonia et al., 2006). Considering the small size of a feline ureter, the risk of an anastomosis to fail, the severe hydronephrosis and the normal function of the contralateral kidney, nephrectomy was successfully performed.

This condition is most prevalent in men than women (3:1 ratio) (Bhattacharjee et al., 2016) and this fact can be observed in cats as well (Steinhaus et al., 2015). It is almost exclusive right sided (Bass et al., 2000), except in cases with situs viscerum inversus, a genetic defect in which the organs suffer a left-right inversion asymmetry or duplication of the CVC (Bélanger et al., 2014). This report presents a case of a 
right $\mathrm{RU}$, agreeing to the proportion found in other papers about the affected side, as well as the sexual predisposition.

To our knowledge, RU has been reported in 143 cats (Cornillie et al., 2006; Zaid et al., 2011; Bélanger et al., 2014; Casteleyn et al., 2015; Steinhaus et al., 2015), in which 115 were postmortem (i.e. no clinical relevance or kidney impairment) and 26 had ureteral obstruction due to calculi or stricture (Cornillie et al., 2006; Bélanger et al., 2014; Steinhaus et al., 2015; Casteleyn et al., 2015). In our case report, no previously reported cause of obstruction could be found suggesting that the mechanical compression against the adjacent structures could be the cause of hydronephrosis.

\section{CONCLUSION}

Retrocaval ureter should always be considered as a differential diagnosis of hydronephrosis and hydroureter in cats, especially when imaging exams such as ultrasonography and radiography do not show calculi or any evident cause of intra or extraluminal obstruction.

\section{REFERENCES}

BASOK, E.K.; YILDIRIM, A.; TOKUC, R Type I and II circumcaval ureter in children: experience in three cases. Adv. Ther., v.25, p.375-379, 2008

BASS, J.E.; REDWINE, M.D.; KRAMER, L.A. et al. Spectrum of congenital anomalies of the inferior vena cava: Cross-sectional imaging findings. Radiographics, v.20, p.639-652, 2000.

BÉLANGER, R.; SHMON, C.L.; GILBERT, P.J.; LINN, K.A. Prevalence of circumcaval ureters and double caudal vena cava in cats. Am. J. Vet. Res., v.75, p.91-95, 2014.
BHATTACHARJEE， L.C.S.; SANGA， S.; GUPTA, P.; GEORGE, R.A. Retrocaval ureter or preureteral vena cava: Lest we forget this rare cause of hydronephrosis. Med. J. Armed Forces India, v.72, p.77-79, 2016.

CASTELEYN, C.; CORNILLIE， P.; VAN CRUCHTEN, S.; VAN GINNEKEN, C. Left retrocaval ureter around the ipsilateral limb of a double caudal vena cava in a cat. J. Comp. Pathol., v.152, p.313-316, 2015.

CORNILliE, P.; BATEN, T.; SIMOENS, P. Retrocaval ureter in a cat. Vet. Rec., v.159, p.2525, 2006.

DUCONSEILLE, A.C.; LOUVET, A.; LAZARD, P. et al. Imaging diagnosis - left retrocaval ureter and transposition of the caudal vena cava in a dog. Vet. Radiol. Ultrasound, v.51, p.52-56, 2010.

EVANS, H.E.; DE LAHUNTA, A. (Eds.). Miller's anatomy of the dog. 4.ed. St. Louis: Saunders Elsevier, 2013. 850p.

HOROWITZ, C.; BERENT, A.; WEISSE, C. et al. Predictors of outcome for cats with ureteral obstructions after interventional management using stents or a subcutaneous ureteral bypass device. J. Feline Med. Surg., v.15, p.1052-62, 2013.

SALONIA, A.; MACCAGNANO, C.; LESMA, A. et al. Diagnosis and treatment of the circumcaval ureter. Eur. Urol. Suppl., v.5, p.449462, 2006.

STEINHAUS, J.; BERENT, A.C.; WEISSE, C. et al. Clinical presentation and outcome of cats with circumcaval ureters associated with a ureteral obstruction. J. Vet. Intern. Med., v.29, p.63-70, 2015.

ZAID, M.S.; BERENT, A.C.; WEISSE, C.; CACERES, A. Feline ureteral strictures: 10 cases (2007-2009). J. Vet. Intern. Med., v.25, p.222229, 2011. 